Rear Admiral E. G. Irving, O.B.E.

Risar Admrac Irving, who succeeds as hydrographer of the Navy, joined H.M.S. Royal Oak as a cadet in August 1927, afterwards voluntcering for the Surveying Servico in 1931. Since then he has been constantly employed on hydrographic survey work in many parts of the world, including survoys in Sicily and Ttaly and in North-West Europe during wartime operations, when he wo,s awarded the O.B.E. and montionod in dispatches. He has commanded four of Her Majesty's surveying ships and has held the posts of naval assistant to the hydrographer and superintendent of charts in the Hydrographic Department.

Biochemistry at King's College, London:

Prof. W. Robson

Prof. Wruliam Romson, who is rotiring from the chair of biochemistry at King's College in the University of London, is one of London's most sonior biochemists. A graduate of King's College, he returned there in 1927 as lecturer in physiological chomistry. He has boen a member of the Board of Studies in Biochemistry since its formation in 1929 and was appointed reader in biochemistry at King's College in 1931. In 1958 he became the first professor of the subject at King's. Besides many postgraduate studonts who have reason to be grateful to Prof. Robson for his encouragement and guidance, many generations of preclinical students in the London medical schools have had their biochemicel studies influencod and shaped by his wisdom. In his retirement, Prof. Robson will have the satisfaction of remembering the large part he has played for more than thirty yoars in roaring and nurturing biochemistry from lusty infancy in the 'twenties to the promising stripling of the 'sixties.

Prof. H. Harris

Dr. H. Harris, who will succeed Prof. Robson, is best known for his contributions to the study of human genetics by the application of biochemical techniques. Ho graduated in medicine from the Universities of Cambridge and Manchester and then served for three years as a medical officer in tho Royal Air Forco. Ho bocame interested in problems of human genetics during this poriod, and in 1947 began work with Prof. L. S. Penrose in the Galton Laboratory at University College, London, as a Leverhulme Scholar of the Royal College of Physicians. Dr. Harris was quick to realize the potentialities of chromatography and electrophoresis in genetical studies. His increasing requirements for biochemical facilities were met by his appointment to a joint lectureship in the Departments of Genetics and of Biochemistry. In 1953 Dr. Harris was appointed sonior lecturer in the Department of Biochemistry of tho London Hospital Medical College. Generous support from the Rockefeller Foundation from 1956 onabled him to expand his field of work. Dr. Harris has also contributed notably to the development of his subject by the production of his two books, "Introduction to Human Biochemical Genetics" in 1953 and "Human Biochemical Genetics" in 1959. These have prosentod lueid and critical surveys of rapidly expanding research in matters of great human importance.

The Mcdal of the Iron and Steel Institute

The Council of the Iron and Stool Institute has established a now gold medal award, to be known as "The Medal of The Iron and Steel Institute". This Medal is to bo presonted on special occasions to societies which have, in the opinion of the Council of the Institute, rendered exceptionel sorvice to science or industry over a lengthy period. The first award of the Medal is to be mado to the Royal Society, in rccognition of its unique service to seience over a period of three hundred years. The Modal was presented by the Hon. R. G. Lyttelton, past-president of the Iron and Steel Institute, et the Tercentenary Celebrations of tho Royal Society on July 18.

\section{Advisory Council for Research and Development in Fuel and Power}

IT is announced that the Scientific Advisory Council to the Minister of Power has been reconstituted and its terms of reference amended so as to emphasize that its advisory functions cover ell aspects of research and developmont concerned with fuel and power from the laboratory to industrial application. In order to ensure the co-ordination of the advice which the Minister rocoives on research and development matters, the Council will tako over the functions of the Minister's Fuel Efficiency Advisory Committee. This Committeo is accordingly being wound up and the Council is being invited to appoint a standing Committee on Fuel Technology. The mombers of the Advisory Council on Research and Development aro \&s follows : Chairman, Sir Alexander Fleck; Deputy Chairman, Captain (E) W. Gregson; Members, Lieut.-Colonol S. J. M. Auld (oil industry consultant), Dr. C. M. Cawley (chief scientist, Ministry of Power), Mr. T. B. Clark (Imperial Chomical Industries, Ltd.), Sir Josiah Eccles (deputy chairman, Electrieity Council), Mr. W. K. Hutchison (deputy chairman, Gas Council), Dr. W. A. Macfarlane (managing director, National Industrial Fuel Efficioncy Service), Sir Harry Molville (secretary, Department of Scientific and Industrial Research), Mr. L. Rotherham (member for research, Central Electricity Generating Board), Prof. M. W. Thring (University of Sheffield), Dr. F. A. Vick (deputy director, Atomic Energy Research Establishment, Harwell), Mr. A. H. A. Wynn (scientific momber, National Coal Board) ; Assessors, Mr. P. Chantler (economic adviser, Ministry of Power), Dr. E. Lee (director, Stations and Industry Divisions, Department of Scientific and Industrial Research), Mr. H. T. Ramsay (director, Safety in Mines Research Establishment, Ministry of Power); Secretariat, Dr. E. N. Eden and Mr. E. W. Prior (Ministry of Power).

\section{The National Council for Technological Awards}

THE report of the National Council for Technological Awards for the period April 1959-Mareh 1960 records the agrecment of the Minister of Fducation to an amendment of its constitution so as to ensure the inclusion of principals of colleges of advanced technology, and throe such principalsDr. E. C. Edwards, Dr. J. S. Tait and Dr. P. F. R. Venables-have beon nominated by the Minister c, s mombers (Pp. 26. London: National Council for Technological Awards, 1960). During the year, thirteen courses at six colleges were recognized as leading to the Diplome in Tochnology, five courses rejected and seven courses reforred back. Since September 1956, 100 courses in all, at twenty-threo colleges, have been rocognized as leading to the Diploma, and of these eighty-nino havo commenced, and the number of students attending the first year 